\title{
Rudolf Sárdi
}

\section{Nabokov's Cold Pudding}

\section{The Stylistic and Structural Impact of Finnegans Wake on Lolita, Pale Fire, and Bend Sinister}

\begin{abstract}
Vladimir Nabokov was noted for his barbed criticisms on any number of the major 19th and 20th-century writers and their celebrated works. James Joyce is one of the few elect who escapes being tipped into Nabokov's disposal by dint of his extravagant stylistic accomplishment in Ulysses, while Finnegans Wake is wittily described as "a formless and dull mass of phony folklore, a cold pudding." In spite of Nabokov's disdainful comments on Finnegans Wake, this paper attempts to demonstrate the stylistic and structural influences Joyce's work exerted on Lolita, Pale Fire, and Bend Sinister.
\end{abstract}

\section{Punnigans Wake: Nabokov's bête noire}

The fact alone that Vladimir Nabokov protested against all suggestions that any writer had ever influenced his literary craftsmanship has sent many officious academic pigeonholers on an even more sustained pursuit of what would surely have caused the professed insomniac another series of wakeful nights. ${ }^{1}$ Nabokov inveighed against all those who had the courage to challenge the originality of his oeuvre, implying not merely a close kinship with certain literary figures - to which Nabokov would have unreservedly subscribed - but definite influences too. Many such adversaries strove to put him in the same group with names whose mere mention immediately provoked the author's ire. In Strong Opinions Nabokov outspokenly discusses his few likes and numerous dislikes in literature and elsewhere. The list is almost endless, and Nabokov relentlessly poked fun at his bêtes noires, such as Dostoevsky and Freud, who recurrently appear amidst scurrilous attacks as "a slapdash comedian" (42) and "the Viennese quack" (47), respectively. ${ }^{2}$ In an interview, Nabokov was proud to claim that

1. Nabokov's nocturnal habits as a writer are well documented. Brian Boyd writes that "[e]nergy and inspiration could keep [Nabokov] writing for twelve hours at a stretch, often until 4 A.M., and rarely would he be up again before midday" (Vladimir Nabokov: The Russian Years [Princeton: Princeton University Press, 1990], p. 345).

2. All parenthetical references are given to this edition: Vladimir Nabokov, Strong Opinions (New York: McGraw-Hill Book Company, 1973).

The AnaChronisT 14 (2009): 121-134 ISSN 1219-2589 


\section{RUDOLF SÁRDI}

[a]s for influence ... I've never been influenced by anyone in particular, dead or quick, just as I've never belonged to any club or movement. In fact, I don't seem to belong to any clear-cut continent. I'm the shuttlecock above the Atlantic, and how bright and blue it is there, in my private sky, far from the pigeonholes and the clay pigeons.

(Strong Opinions 116)

What in this passage develops into some lighthearted Nabokov wordplay is but the austere disavowal of the existence of most "antecedents" who might have been given a crucial role in sculpting the author's fictional worlds in more ways than one. Interestingly enough, James Joyce appears as one of the few literary figures whose art Nabokov did not entirely dislike, even though was known to have "operated a landfill for literary reputations into which he tipped any number of the late nineteenth century's prominent authors and their acclaimed works."3

In several of his interviews and one penetrating lecture on literature that Nabokov delivered at Cornell University, he ranked Ulysses high on a scanty list of his preferences; at the same time other works of the Irish master remained callously underrated or unmentioned. Finnegans Wake and A Portrait of the Artist as a Young Man both appear at the fag-end of Nabokov's carefully compiled list. 4 In one of his famous "strong opinions" Nabokov declared his genuine admiration for Ulysses. 5 Despite the claim made by Alfred Appel, Jr. that Nabokov "consciously profited from Joyce's example without imitating him" (Strong Opinions 72), the author himself insisted that he had learned "nothing" at all from the author of Punningans Wake, as he once wittily referred to the novel (Strong Opinions 102). In his discussion of Joyce's Finnegans Wake, ${ }^{6}$ the author openly admits to being a night-owl when he rejects the novel as "nothing but a formless and dull mass of phony folklore, a cold pudding of a book, a

3. Julian Moynahan, "Nabokov and Joyce," in The Garland Companion to Vladimir Nabokov, ed. Vladimir E. Alexandrov (New York: Garland, 1995), p. 433.

4. Shortly after Nabokov had moved to America, he launched his survey course, "Masterpieces of European Fiction," at Cornell University (1950-1959).

5. In a television interview given in 1965 , Nabokov said: "Ulysses, of course, is a divine work of art and will live on despite the academic nonentities who turn it into a collection of symbols or Greek myths. I once gave a student a C-minus, or perhaps a D-plus, just for applying to its chapters the titles borrowed from Homer, while not even noticing the comings and goings of the man in the brown mackintosh. He didn't even know who the man in the brown mackintosh was. Oh, yes, let people compare me to Joyce by all means, but my English is patball to Joyce's champion game" (TV-13 NY [1965]). His fascination with Ulysses is also reflected in Nabokov's plan to translate the novel into Russian, so much so that he even sought Joyce's permission to do so.

6. Alfred Appel, Jr. and Vladimir Nabokov, "An Interview with Vladimir Nabokov," in Wisconsin Studies in Contemporary Literature, A Special Number Devoted to Vladimir Nabokov, 8.2 (Spring 1967) 127-152. p. 137. 
persistent snore in the next room, most aggravating to the insomniac I am." Nevertheless, it has been convincingly proven that the structural and stylistic oddities of Joyce's works, including his much-derided Finnegans Wake, resonate powerfully in Nabokov's novels written during his American period. One may easily detect numerous analogies between the writings of Joyce and Nabokov, who both heartily encourage their readers to embark on a journey of intellectual adventures. Artistic independence, verbal prestidigitation, unorthodox speech and linguistic patterns, experimentation, authorial alter egos, the widespread use of obscure allusions, and imaginary, unknown lands of conundrum-laden languages which create an air of verisimilitude, while always keeping the reader at a distance from true reality are only an exiguous number of examples connecting the two writers. The present paper, however, will not undertake the insurmountable task of identifying the innumerable echoes of Joyce in Nabokov's works, nor does it intend to study the oft-discussed literary relationship between the two authors.7 Instead, it examines how the structure, language, and style of Finnegans Wake have been partially incorporated into Nabokov's text. The examination of the circular structures of Giambattista Vico underlying Finnegans Wake and the Joyce-like constant of fluidity will provide the basis of the following discussion. Paramount to the elaboration of my argument is the fact that Nabokov only sought to employ an incomplete portion of Joyce's techniques in Finnegans Wake. As regards the entirety of his techniques, it would be virtually impossible to measure Joyce's work to any novel written by Nabokov. Knowing that the proof of the pudding - however cold it may be - is in the eating, I shall attempt to test certain Joyce-like paradigms on Lolita, Pale Fire, and Bend Sinister, where both the latent and the manifest influence of Finnegans Wake are perceptible.

Since its publication in 1939 the reading of Finnegans Wake has remained one of the most redoubtable tasks that readers were to tackle during the sixty-odd years of painstaking philological work surrounding Joyce's well-known "work-in-progress." If the experimental gimmicks widely utilized in Ulysses prove how a novel can break loose from its hinges, then Finnegans Wake signifies the limits of representation. John Gross has claimed that in Finnegans Wake "words take on a capricious life of

7. In addition to the oft-documented allusions to Joyce in Nabokov's work, scholars often call attention to the personal encounters between the two luminaries of twentieth-century literary life. In one interview Nabokov claims to "have dined with Joyce and have had tea with RobbeGrillet" (The Sunday Times, 1969); and, on another occasion, Nabokov was delivering a speech in Paris (instead of Jolán Földes, a Hungarian writer) and described his encounter with the Irishman as follows: "A source of unforgettable consolation was the sight of Joyce sitting, arms folded and glasses glinting, in the midst of the Hungarian football team" (Boyd, p. 434).

8. Roland McHugh's Annotations to Finnegans Wake is a case in point (London: Johns Hopkins University Press, 1980). 


\section{RUDOLF SÁRDI}

their own," 9 and it seems that even today many readers are exasperated by the apparent unintelligibility of its language..$^{10}$ In 1926 Joyce sent a letter to Harriet Shaw Weaver, providing an explication for the rationale of Finnegans Wake: "Today I restarted. One great part of every human existence is passed in a state which cannot be rendered sensible by the use of wideawake language, cutanddry grammar and goahead plot."11 It is true of Finnegans Wake that its verbal experimentation calls for an "activity not dissimilar from that of the translator."12 In like manner, many of Nabokov's later works (especially the magically flowing style of Ada or Ardor: A Family Chronicle) have also aroused critical controversy about their modes of representation and about the extent to which the stylistic bravura of the author obfuscates the general comprehension of his readers. The intricately patterned works of meta-fiction for which Nabokov has enjoyed an enviable reputation often seem to require translation, or, rather, the deciphering of not purely linguistic but cultural, historical, and biographical codes as well. While in the case of the polyglot Russian-American writer the unconventionality of style and language only constitutes one, but all the more significant part of the novels, Finnegans Wake turns into a vast lexical playfield, where the reader must provide his own subjective annotations and may cast aside all the predefined solutions that Wake scholars have relentlessly forced on the consumers of Joyce's text. ${ }^{13}$ "Words in Finnegans Wake, with their deliberately ambiguous orthography, offer an invitation to the reader to use his puzzle-solving ingenuity and imagination with an arbitrariness which, in turn, is certainly licensed by Joyce's implied purpose in creating the text." 14

9. John Gross, Joyce (London: Fontana/Collins. 1971), p. 76.

10. Gross, p. 77.

11. Cited in Pieter Bekker, "Reading Finnegans Wake," in James Joyce and Modern Literature, ed. W. J. McCormack and Alistair Stead (London: Routledge \& Kegan Paul, 1982), p. 187.

12. Cited in Bekker, p. 185.

13. Ada or Ardor: A Family Chronicle, Nabokov's richest and most passionate novel, is a highly revealing example of the role of languages in his novels as opposed to the Joyce world of Finnegans Wake. Set in the imaginary land of Antiterra (or Demonia), Nabokov integrates three existing countries (Russia, France, and the United States) into a single geographical space which appears to be strikingly similar to our own world. The code-switching among and the occasional convergences of the three different languages (Russian, English, and French), which are simultaneously spoken in Nabokov's "familiar-yet-alien make-up of the projected world" (Brian McHale, Postmodernist Fiction [New York: Methuen, 1987], p. 19), are a clear indication of a slightly distorted yet recognizable locus of events, while the setting and language spoken in Finnegans Wake remain obscure and irrational, making the reader's task more enigmatic and puzzling than was Joyce's original intent at the time of publishing Ulysses.

14. Ferenc Takács, Szombathelyi Joyce/The Joyce of Szombathely (Szombathely: Önkormányzat, 2005), p. 6. 
Sailing through the indisputably rough seas of Finnegans Wake may very well remind the reader of the absurd coinages and portmanteaux of Lewis Carroll's Jabberwocky and the long tradition of nonsense verse in Anglo-American literature. One must, however, note that Joyce's idioglossia is far more convoluted in its dimensions, as the "eclectic and eccentric erudition [Joyce] accumulated along the way" should, in some measure, also be at the disposal of a generation of postmodern readers. Perhaps they are better prepared to produce (rather than consume) an avant-garde text gravitating toward occultation, that is, a disorienting experience owing to the multiple meanings the text accommodates, instead of offering the kind of pleasure one would expect from an essentially readerly text. ${ }^{15}$ I strongly agree with Gross, who endorses the view that "Wake-talk is anything but empty gibberish ... On the contrary, what we have to contend with while trying to decipher it is an unmanageable excess of meaning - or rather, of secondary meanings, minor associations and allusions which continually send the reader off at a tangent." 16 Whilst the polysemy of Joyce's text has discouraged many readers from experiencing the enchantments of the unwearied philologist, it is worthy of note, as Margot Norris also asserts, that "the text's 'unreadability' becomes [for others] not an obstacle, but a cause for appreciation." ${ }^{17}$

\section{Children-colors in Lolita}

Cryptic as certain literary allusions may appear throughout Nabokov's works, Lolita seems to comprise numerous echoes of Joyce, including a fairly straightforward example of an intentional allusion to Finnegans Wake. ${ }^{18}$ Several eisegetes of Nabokov's texts were long preoccupied with the possible congruence between HCE (Humphrey Chimpden Earwicker) and Lolita's Humbert, whose name is transfigured into different droll forms, implying occasional coincidences "with a few of Joyce's punning phonetic variants." ${ }^{19}$ Of course, as would be expected of a Nabo-

15. Margot Norris, "Finnegans Wake," in The Cambridge Companion to James Joyce, ed. Derek Attridge (Cambridge: Cambridge University Press, 2004), p. 159.

16. Gross, p. 78.

17. Norris, p. 157.

18. Careful readers and re-readers of $A d a$ will also take cognizance of how deftly Nabokov ingrains another direct reference to Finnegans Wake. He writes: "Did he like elms? Did he know Joyce's poem about the two washerwomen? He did, indeed. Did he like it? He did" (Ada 48). In the online annotations to Ada, Brian Boyd points out that the line alludes to the end of the "Anna Livia Plurabelle" chapter (Book One, Chapter 8) of Finnegans Wake, where "Tell me," in its last transformation becomes "Tell me, tell me, tell me elm! Night night! Telmetale of stem or stone" (Ada Online, http://www.ada.auckland.ac.nz).

19. Alfred Appel, Jr., ed. "Notes," The Annotated Lolita, by Vladimir Nabokov (London: Penguin, 2000), p. 414. See notes $221 / 1$ in The Annotated Lolita for a list of examples (pp. 


\section{RUDOLF SÁRDI}

kov bereft of influences of all sorts, this is but mere speculation or coincidence, because Joyce's novel is "a very small and blurry smudge on the mirror of my memory," as the writer of Lolita claimed. ${ }^{20}$ Even so, a conscious allusion to the Wake is made in Lolita. In his tortuous memoir, Humbert depicts a memorable scene where he and Lolita attend a play, whose exact plot he is unable to recall, but writes that

[t]he only detail that pleased me was a garland of seven little graces, more or less immobile, prettily painted, bare-limbed ... and were supposed to represent a living rainbow, which lingered throughout the last act .... I remember thinking that this idea of children-colors had been lifted by authors Clare Quilty and Vivian Darkbloom from a passage in James Joyce.

(AL 220-221, my emphases)

Clare Quilty, the playwright, and Vivian Darkbloom, his arcane collaborator, plump for a passage from Finnegans Wake in lieu of another work by Joyce venerated by Nabokov. Appel, who considers the "seven little children" to stand for the colors of the rainbow, persuasively explains that the Wake begins - or rather, opens - with a reversed rainbow, in which each clause of the second paragraph makes use of a color. ${ }^{21}$ In fact, Joyce's "living rainbow" is not only condensed into the short opening section of the Wake but prevails throughout the whole book. Whether we are confronted with Humbert's inadvertent misreading of the book (unorthodox for the learned litterateur, unless his reading of it lies in its unreadability, as scholars would often put it) or a simple test of our erudition and conversance with the Wake is a question left on an indeterminate note. The one thing to be taken for granted is that Quilty's preference of what to "lift" from the Wake and not from another, less disparaged work by Joyce is likely to correspond with Nabokov's own choice. This

413-414). Much as I appreciate the meticulous philological work of Nabokovians whose main interest lies in the formalistic aspects of the author's fictional universe, such hypotheses, to my mind, are mostly groundless, hence unconvincing. This conviction is especially pertinent in the case of Finnegans Wake, a novel whose allusiveness and titanic holding capacity accommodate anything and anyone reverberating later in world literature.

20. Vladimir Nabokov, The Annotated Lolita, ed. Alfred Appel, Jr. (London: Penguin, 200o), p. 414. Small and blurry as it is, Nabokov was among the first to peruse a copy of Haveth Childers Everywhere, a fragment of Joyce's tour de force, written eight years before its publication in toto (1938). Brian Boyd writes that Joyce himself handed over the copy to Nabokov at a dinner invitation at Paul Léon's home (Boyd, p. 504).

21. Joyce's Use of Colors: Finnegans Wake and the Earlier Works by J. Colm O'Sullivan offers an interesting insight into the color patterns of the Wake. In it, he claims that Joyce's reason for utilizing patterns of color associations is the fundamental ordering device in the novel, employed for the purpose of finding what these patterns are and elucidating the themes of the work, which would otherwise require superhuman efforts to unravel. 
assumption might be confirmed if one supposes that Vivian Darkbloom, vile Quilty's collaborator, also helps the playwright make his choice; or, on the contrary, one might conclude that Quilty is the one helping Darkbloom, whose full name is an anagram for Vladimir Nabokov - deus absconditus, or rather, a semi-hidden god, who has retired, as it were, from the world he had created but has not yet grown entirely weary of involvement in his fictional universe. In light of this frequent observation on the constructing of anagrams in Lolita, it should come as no surprise that Darkbloom/Nabokov alludes to Finnegans Wake - a hateful choice of a hateful character.

\section{Finnigan's Wake in Pale Fire, Winnipeg Lake in Bend Sinister}

The cycloramic view of world history in Finnegans Wake calls to mind the wellknown influence of Giambattista Vico, who argued in Scienza Nuova that civilization is but a recurring cycle and has therefore become the progenitor of the unconventional structure of Joyce's novel, journeying on the river Liffey as the reader's cicerone. The "commodius vicus" of the first paragraph is often read as a direct reference to Vico's cyclical theory of history; the rump sentence with which the novel sets off also provides the continuation of the concluding sentence of the book ("A way a lone a last a loved a long the [628] ... riverrun, past Eve and Adam's, from swerve of shore to bend of bay brings us by a commodius vicus of recirculation back to Howth Castle and Environs [3]). ${ }^{22}$ The fact alone that the book begins where it ends is more than likely to have exerted an influence on some of Nabokov's work, particularly on the creation of Pale Fire, a quintessentially postmodernist work, whose circular pattern is akin to that of Joyce's text. Pale Fire is a blending of literary genres: it consists of a Foreword, a 999-line poem in heroic couplets ("Pale Fire”) by the fictional poet, John Shade, and followed by a lengthy commentary (supposedly written on index cards) by a self-appointed editor, Charles Kinbote, alias King Charles "The Beloved," who claims himself to be the exiled king of the imaginary "distant northern land" of Zembla. John Shade was assassinated before he could complete his poem, which lacks only one line. The manuscript is acquired by Kinbote, who edits and copiously annotates the poem; however, instead of explicating the nuances of Shade's text, Kinbote recounts his circuitous flight from Zembla by alluding to selected parts of the poem. In the Foreword, Kinbote hypothesizes that "there remained to be written only one line of the poem (namely verse 1000) which would have been identical to line 1 and would have completed the symmetry of the structure." ${ }^{23}$ The annotation of the non-existing line 1000 swerves the reader

22. James Joyce, Finnegans Wake (New York: Penguin Books, 1976), p. 3.

23. Nabokov, Pale Fire, p. 8 (emphasis in the original). 


\section{RUDOLF SÁRDI}

back to the opening line; and in doing so, the recurring cycle establishes the elaborately drawn, circular shape of the novel. It is worthwhile to look at how the title of the last index card ("Line 1000 [= Line 1: I was the shadow of the waxwing slain]" [PF 206]) stitches together the opening and closing lines of "Pale Fire," the poem:

But it's not bedtime yet. The sun attains

Old Dr. Sutton's last two windowpanes.

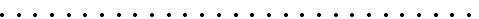

And through the flowing shade and ebbing light

A man, unheedful of the butterfly -

Some neighbor's gardener, I guess - goes by

Trundling an empty barrow up the lane. ${ }^{24}$

I was the shadow of the waxwing slain

By the false azure in the windowpane;

I was the smudge of ashen fluff - and I

Lived on, flew on, in the reflected sky. ${ }^{25}$

However, it seems to me that Vico's theory of corsi and ricorsi alone may not be able to provide irrefutable evidence for the similarities between the two works because circularity is not exclusively a feature of Joyce's works, in literature. The only reason why I find this resemblance between Pale Fire and Finnegans Wake especially striking is because the poem's (apparently) end-stopped last line is smoothly held over by the opening line, as demonstrated above. In the Foreword, Kinbote asserts with conviction that Shade had a "combinational turn of mind and subtle sense of harmonic balance," which would have prevented him from shattering the mirror-like symmetry of his composition. It is then Kinbote who overrules Shade's authorial decision by arbitrarily gluing line 1000 to the poem, and, in place of an annotation proper, he begins to weave his own story. Should the reader concur or not with Kinbote's speculation concerning the "missing line"? Is he, as the editor of Shade's text, allowed so much freedom that he can even fabricate his own story from bits and pieces of the poem? Although Nabokov himself claimed that Finnegans Wake "has no inner connection with Pale Fire" (Strong Opinions 74), Annalisa Volpone believes that, in addition to the circular pattern, there are common features which create an intimate link between the two texts. ${ }^{26}$ Volpone's assertion

24. Nabokov, Pale Fire, p. 29 (line 999; emphasis added)

25. Nabokov, Pale Fire, p. 49 (line 1; emphasis added)

26. Annalisa Volpone, "'See the Web of the World': The Hypertextual Plagiarism in Joyce's Finnegans Wake and Nabokov's Pale Fire," in Nabokov Online Journal 3 (2009), August $2009<$ http://etc.dal.ca/noj/volume3/articles/o5_Volpone.pdf $>$. 
that the novels have a narrative structure that calls for the reader's active involvement in the process of reading brings to mind Barthes' idea of writerly texts, according to which the consumer of the text becomes its producer (or rather, author). ${ }^{27}$ Such is the case of Joyce's and Nabokov's novels, both of which challenge the reader's traditional notion of reading by disrupting the narrative flux of the text with a structure and a verbal extravagance (much more so in the case of Joyce) which incapacitates the reader from unthinkingly consuming or enjoying the story. ${ }^{28}$ It is the non-linear, non-sequential, and fragmented nature of both novels (with their occasional and incessant linguistic experimentation, respectively) that compels the reader to "re-establish formal hierarchies" by attempting to "define the author's role both in $F W$ and $P F$, since it must be negotiated and reconfigured page after page." ${ }_{29}$ Aside from the rich referentiality of both novels, the herculean task one must tackle in Finnegans Wake is dealing with its alien yet strangely familiar language, while in the case of Pale Fire the non-sequential arrangement of the index cards and the deliberately misleading editorial instructions (Kinbote's irksome commands as to how the reader should hopscotch among the annotations) cause the reader to advance watchfully. Irrespective of the level of vigilance exercised as one proceeds, one cannot but realize that there is no ready-made solution as to the proper way of reading either novel, and that the reader is invested with the power to establish his or her textual supremacy over the narrative discourse. The coinages of "Finneganese" are endowed with multiple meanings, and it is largely dependent upon the reader how he or she interprets a word or a phrase. As regards Pale Fire, it is not only Kinbote who can take the liberty of imposing his own story upon the text, but the readers are also silently urged to read, decode, and reinterpret the novel as they please.

In the commentary appended to line 12, Kinbote openly alludes to Joyce's work by sustaining Nabokov's repugnance for Joyce's novel. Much to the reader's satisfaction, Nabokov's disapproval of Finnegans Wake is combined with his devious wit in the passage that follows. Kinbote believes that delivering a lecture on Finnegans Wake is far more fitting for a scholar than subjecting Ulysses to critical scrutiny.

Of course, it would have been unseemly for a monarch to appear in the robes of learning at the university lectern and present to rosy youths Fin-

27. Volpone uses the term "hypertextual narrative" as a suitable expression to characterize Joyce's and Nabokov's textualities. She says "[t]hey do not write their novels consecutively, chapter after chapter, page after page. Rather, they juxtapose episodes and crucial narrative events following a personal mental pattern, which highly affects their unconventional prose.”

28. Roland Barthes, $S / Z$, trans. Richard Miller (New York: Hill and Wange, 1974), passim. 29. Volpone. 


\section{RUDOLF SÁRDI}

nigan's Wake [sic] as a monstrous extension of Angus MacDiarmid's 'incoherent transactions' and of Southey's Lingo-Grande ('Dear Stumparumper,' etc.).30

In her ingenious commentary of the above passage, Volpone clearly supports the validity of her argument that plagiarism and thievery are symptomatic of both Joyce's and Nabokov's texts both on the linguistic and thematic levels. She considers Pale Fire to be "a masterpiece that is surreptitiously built on the practice of purloining," as the title of Nabokov's novel derives from Shakespeare's Timon of Athens:

I'll example you with thievery:

The sun's a thief, and with his great attraction

Robs the vast sea; the moon's an arrant thief,

And her pale fire she snatches from the sun. ${ }^{31}$

Nabokov's allusion to Shakespeare's work is the first instance of literary "theft" in the production of Pale Fire. The second theft occurs - now at the intradiegetic level - as Kinbote appropriates Shade's poem to attach to it his apparatus criticus, which turns out to be his misuse of "Pale Fire" (the poem) by his heavy reliance on Shade's words to fabricate his own narrative. The Commentary thus "parasitically draws life from the dissected main text [the poem], whose broken sentences and words are recycled for a different narrative." ${ }^{2}$

In addition to Pale Fire, where the cyclical configuration of Joyce's text imposingly resonates, Bend Sinister, Nabokov's dystopian novel, also abounds in allusions to Finnegans Wake. The novel is set in an illusory Central European country whose inhabitants speak both German and Russian, and a moment later an amalgamation of the two, making Bend Sinister less accessible to the common reader than many of Nabokov's other books; yet the occasional snatches of a foreign tongue are still a far cry from the weirdly looping sentences of Finnegans Wake. In his

30. Nabokov, Pale Fire (New York: Lancer Books, 1963), p. 55.

31. William Shakespeare, Timon of Athens, August $2009<\mathrm{http}: / /$ www.gutenberg.org/ dirs/etext98/2ws3710.txt> (my emphasis).

32. In Volpone's reading, Hugh MacDiarmid's emergence in the previous passage from Pale Fire is a highly revealing example of how thievery connects Joyce's text with that of Nabokov. A prominent member of the "Scottish Renaissance," MacDiarmid was instrumental in establishing a national tradition for Scotland, akin to Macpherson, the controversial "translator" of the still debated Ossian cycle of poems. Volpone writes that "[s]imilarly to MacPherson, Joyce is (re)creating a national epic, intentionally forging a tradition that does not exist. From this perspective, the Wake becomes for Kinbote the highest example of literary deceit, a model reference to make Zembla more tangible. Indeed, to turn his imaginary land into a real place, Kinbote needs to endow it with a national history, a culture and, of course, a language." 
article, Michael H. Begnal explains that both Giordano Bruno and Giambattista Vico appear in Bend Sinister as: "Hamlet at Wittenberg, always late, missing G. Bruno's lectures” (112) 33 and “... suited his liquidity to a tee: $c p$. Winnipeg Lake, ripple 585, Vico Press edition” (114).

Begnal then goes on to add that '[t]he 'p' in 'cp,' instead of 'cf,' might be explained by the fact that the river god Alpheus mentioned in the text just before contains the initials of ALP [Anna Livia Plurabelle] and is also the last name of the river Heracles [sic] used to cleanse the Augean Stables." 34 Joyce's fascination with liquidity, bodily functions, and fluids is a dominant feature of his texts. Margot Norris also notes that the "sinuous sentence" introducing Finnegans Wake "continues a journey: by water, by bodily fluid, by verbal fluency." 35 Several sources underscore the importance of lexical items pertaining to the discharge of bodily fluids (micturition, defecation, and the like), which, among other things, are meant to buttress the smoothly flowing structure of the novel, which is reminiscent of the cyclical movement of natural waters. In Ojibwa, an Algonquian Indian dialect, the town name "Winnipeg" (in Bend Sinister) indicates "filthy stream," affording justification for the preponderance of lighthearted punning in matters pertaining to bodily functions in Finnegans Wake. ${ }^{6}$ In Bend Sinister Nabokov makes a deliberate and very successful attempt at reproducing Joyce's idioglossia, more precisely, the wellknown river speech of the novel: "Lithe, lithping, thin-lipped Ophelia, Amleth's wet dream, a mermaid of Lethe" (114). It is interesting to note that the numerous allu-

33. All parenthetical references are given to this edition: Vladimir Nabokov, Bend Sinister (New York: McGraw-Hill, 1974).

34. Michael H. Begnal, "Bend Sinister: Joyce, Shakespeare, Nabokov,” in Modern Langauge Studies 15 (1985) p. 23.

35. Norris, p. 24.

36. In his discussion of Hungarian in-jokes (jokes meant for an audience that has access to cultural and linguistic codes readers of other nationalities cannot understand), Ferenc Takács brings forward as evidence several examples of Hungarian and non-Hungarian puns alluding to the excretion of bodily fluids. The passage he cites in his article "Joyce and Hungary" seems intelligible for speakers of Hungarian: "it came straight from the noble white fat, jo, opewide sat, jo, jo, her why hide that, jo, jo, jo the winevat, of the most serene magyansty az archdiochesse, if she is a duck, she's a douches, and when she has a feherbour snot her fault" (cited in Takács, p. 8). "Feherbour" (Hungarian "fehérbor" means "white wine") serves as a reference to the urine; "snot" indicates the mucus from the nostrils; "douches" is a double entendre, both pointing to the noble birth of the woman described and calling to mind the irrigation of the vulva, administered by a douche-bag. The passage continues: "now is it? artstouchups, funny you're grinning at, fancy you're in her yet, Fanny Urinia" (FW 171). Here the name "Fanny" denotes the female genitalia in argot, and the name of Urania (the muse of astrology in Greek mythology, meaning "heavenly") is also changed to signify bodily fluids. 


\section{RUDOLF SÁRDI}

sions to Finnegans Wake are not simply interwoven into the disjointed sections of the novel but also dominate its plot structure at large. Speakers of Russian are more likely to make this assertion, since the name of Adam Krug, the protagonist, is a double entendre: it means "circle" in Russian and "jug" in German. It is this circle that encompasses the whole microcosm of the novel and sets apart Krug's "mirok," his inner world, from the "mir," or the world that exists outside him. ${ }^{37}$ The circle of the novel is similar to the corresponding patterns of Finnegans Wake. The beginning and ending of Bend Sinister are thus worth observing to see how the "puddle" of the following passages is used to fabricate the framework of the novel:

An oblong puddle inset in the coarse asphalt; like a fancy footprint filled to the brim with quicksilver; like a spatulate hole through which you can see the nether sky. Surrounded, I note, by a diffuse tentacled black dampness where some dull dun dead leaves have stuck. Drowned, I should say, before the puddle had shrunk to its present size.

(23, my emphasis)

I could also distinguish the glint of a special puddle (the one Krug had somehow perceived through the layer of his own life), an oblong puddle invariably acquiring the same form after every shower because of the constant spatulate shape of a depression in the ground. (212, my emphasis)

If one concurs with the somewhat recursive yet pertinent statement of William York Tindall that "Finnegans Wake is about Finnegans Wake ... about everything," then a similar observation can be made about the all-encompassing quality of Nabokov's work, too. $3^{8}$ Critics have claimed that Nabokov's Bend Sinister is as much a dream as Finnegans Wake, in which the "I" of the novel is the dreamer of a dream. Krug is not only the dreamer but also the participant in it; and there appears in the plot "a nameless, mysterious genius who took advantage of the dream to convey his own peculiar code message ... the presence of someone in the know," who is identified in the Introduction as "an anthropomorphic deity impersonated by me" (Bend Sinister 64 and xii). In his famous lecture on Ulysses Nabokov speculates at

37. “Oh, 'philosophy.' You know. When you try to imagine a mirok [small pink potato] without the least reference to any you have eaten or will eat" (Bend Sinister 18). The "mirok" of the sentence is the diminutive of the Russian word "mir," denoting world. In Pnin, the eponymous hero purchases a soccer ball for his son, and, much to the surprise of the shop assistant "with wrists and palms he outlined a portable world. It was the same gesture he used in class when speaking of the 'harmonical wholeness' of Pushkin" (Vladimir Nabokov, Pnin [London: Penguin, 200o], p. 82).

38. William York Tindall, A Reader's Guide to James Joyce (London: Thames and Hudson, 1970), p. 237. 
length as to the identity of the Man in the Brown Macintosh, who reappears in the novel on several occasions: 39

Do we know who he is? I think we do. The clue comes in chapter 4 of part two, the scene at the library. Stephen is discussing Shakespeare and affirms that Shakespeare himself is present in his, Shakespeare's, works. Shakespeare, he says, tensely: "He has hidden his own name, a fair name, William, in the plays, a super here, a clown there, as a painter of old Italy set his face in a dark corner of his canvas..." and this is exactly what Joyce has done - setting his face in a dark corner of his canvas. The Man in the Brown Macintosh who passes through the dream of the book is no other than the author himself.40

Just as Joyce orchestrates the diverse elements of Earwicker's dream, so too does Nabokov keep authorial control over those of Krug and everything else he had created in his private, fictional world. ${ }^{41}$ The fact that Krug is but another of a series of authorial alter egos (the aforementioned "anthropomorphic deity" of the Introduction) proliferating in Nabokov's novels also establishes an intimate connection with Joyce's doubles all through his career.42

\section{Conclusion}

I have claimed in the foregoing that a similitude of techniques in the works of the two masters calls for stimulating discussions. Whilst the experimental language of Finnegans Wake and Joyce's methods of unimpeded stream-of-consciousness often come close to being impenetrable, both the novel's circularity at the most obvious linguistic level and the prevalent theme of fluidity make its reading highly entertaining and, at a local level, fairly transparent. In addition to several other components of the Joyce heritage that Nabokov skillfully integrated into his own texts, it is the stylistic accomplishment of both writers within the literary traditions that places them on nearly equal footing. The sinuously constructed, literally

39. For a discussion of authorial self-representation in Ulysses and Lolita, respectively, see Ákos I. Farkas, “As McFate Would Have It: The Author's Joycean Cameo in Lolita," in the present issue of The AnaChronist (111-120).

40. Vladimir Nabokov, "Ulysses," in Lectures on Literature, ed. Fredson Bowers (New York: Harcourt Brace Jovanovich, 1980), pp. 319-320.

41. Begnal, p. 25.

42. See my MA thesis, "The Questions of Identity in Nabokov's Fiction," for a detailed discussion on doubles and novelistic self-representations in Nabokov's Despair and Lolita (Budapest: Eötvös Loránd University, 2006). 


\section{RUDOLF SÁRDI}

overflowing story of Finnegans Wake has clearly found its way into Nabokov's fiction under the name "cosmic synchronization" in Speak, Memory. J. B. Sisson, who has offered the most systematic treatment of the subject to date, describes "cosmic synchronization" as "the posited desire of the artist to apprehend the entire universe by an awareness expanding rapidly outward from the artist's consciousness. ... This process ideally occurs so rapidly as to create an effect of instantaneity." 43 As opposed to Finnegans Wake, Nabokov's cosmically synchronized scenes create the impression that the novel is composed of disparate elements; but then these elements, "by a process of imagined superimposition," 44 come together in a unified, synchronous whole, a concatenation of images, constituting pieces of a huge puzzle waiting to be assembled in the very fashion the "anthropomorphic deity" of the text enjoins. Nabokov's raison d'être for thinking unsympathetically of some of Joyce's novels is elucidated by a fleeting reference to "poor Stream of Consciousness, marée noir [black tide] by now" in Ada.45 To Nabokov, the unrestrained and continuous flow of self-perceptions and feelings is unsatisfactory, because, he claims, an ordering principle in both art and life is indispensible; disjointed fragments and unconnected thought-processes ought to be consciously arranged in the intricately patterned designs for which Nabokov is highly credited as a writer. ${ }^{46} \mathrm{It}$ is this dearth of rational and organized thinking that dehumanizes Finnegans Wake and keeps it at a distance from Nabokov's novels. The only rule, one may conclude, to be observed in Finnegans Wake is that there are virtually no rules; or rather, the rules of the game are created as much by the reader as by the writer himself, thereby implying that the most important difference between Joyce and Nabokov is the respective amount of freedom they allow the reader. Nonetheless, it must have been Joyce who taught Nabokov how to compose fiction as if it were a dream. Strangely enough Nabokov remained a wakeful dreamer all his life.

43. J. B. Sisson, "Nabokov's Cosmic Synchronization and 'Something Else," Nabokov Studies 20 (1994), p. 155.

44. Sisson, p. 177.

45. Vladimir Nabokov, Ada or Ardor, A Family Chronicle (London: Penguin Books, 2000), p. 237.

46. In Lolita, Humbert admits to having composed his memoir with an elaborate pattern in mind: "Quietly the fusion took place, and everything fell into order, into the pattern of branches that I have woven throughout this memoir with the express purpose of having the ripe fruit fall at the right moment" (The Annotated Lolita, p. 272). 